\title{
Removal of cobalt(II) and zinc(II) from sulphate solutions by means of extraction with sodium bis(2,4,4-trimethylpentyl) phosphinate (Na-Cyanex 272)
}

\author{
Magdalena Regel-Rosocka ${ }^{1}$ (D) Katarzyna $\operatorname{Staszak}^{1} \cdot$ Karolina Wieszczycka $^{1} \cdot$ \\ Anna Masalska ${ }^{1}$
}

Received: 18 November 2015/Accepted: 5 February 2016/Published online: 19 February 2016

(C) The Author(s) 2016. This article is published with open access at Springerlink.com

\begin{abstract}
The removal of $\mathrm{Co}$ (II) and $\mathrm{Zn}$ (II) from model and real crude nickel sulphate (CNS) solutions by extraction with sodium bis(2,4,4-trimethylpentyl)phosphinate (NaCyanex 272) is studied and compared with the effect of using bis(2,4,4-trimethylpentyl)phosphinic acid (Cyanex 272). The proposed novel approach to manage both hazardous metal ions from CNS with sodium salt of Cyanex 272 focuses on the following issues: (i) effect of the initial $\mathrm{pH}$ of feeds on the extraction efficiency, (ii) leaching of metal ions from CNS, (iii) efficiency and selectivity of metal ion extraction from real CNS, and (iv) FT-IR analysis of structure of complexes formed by the metal ions with the extractant studied. It is concluded that converting Cyanex 272 into its sodium salt greatly improves the efficiency of the extraction in comparison to the conversion into the acidic form of the extractant, regardless of the type of metal ion considered, whether $\mathrm{Zn}$ (II) or $\mathrm{Co}$ (II). These phenomena occurring in the extraction system are confirmed by the obtained FT-IR spectra of the organic phases after extraction and stripping.
\end{abstract}

Keywords Cobalt(II) $\cdot$ Zinc(II) $\cdot$ Liquid-liquid extraction - Crude nickel sulphate solution - Cyanex 272 . Hazardous waste management

Electronic supplementary material The online version of this article (doi:10.1007/s10098-016-1123-1) contains supplementary material, which is available to authorized users.

Magdalena Regel-Rosocka

magdalena.regel-rosocka@put.poznan.pl

1 Faculty of Chemical Technology, Institute of Chemical Technology and Engineering, Poznan University of Technology, Berdychowo St. 4, 60-965 Poznan, Poland

\section{Introduction}

Hydrometallurgical processing of ores and concentrates (the so-called wet method) involves the use of aqueous solutions for extraction of metals, and the majority of their compounds, from primary deposits (Cole and Sole 2003; Ritcey 2006). Liquid-liquid extraction can be applied to the raw materials that cannot be processed pyrometallurgically because of the chemical nature of the processed metal or its low content in the ore.

The strict environmental regulations, diminishing natural resources of metals, their scarce availability, and the ever-growing demand for them (circuit boards, batteries, capacitors, etc.) stimulate the efforts directed at the recovery of metals from spent batteries (Kang et al. 2010; Li et al. 2015), industrial sludges (Kumar et al. 2013; Sethu et al. 2008) and wastewater streams (Reddy and Park 2007). An example are copper electrorefineries that, besides cathode copper production, produce crude nickel sulphate (CNS) technical grade commercial product sold for its nickel value (Olejnik et al. 2008). Almost all of the nickel contained in copper-bearing ores is concentrated in the final product of smelting process of copper anodes. Spent electrolyte after copper removal is subjected to concentration resulting in the crystallization of nickel sulphate. Its fine crystals after centrifugation form the final product (KGHM 2015). CNS is composed of mainly Ni(II) (25-30\%), about $0.5 \% \mathrm{Co}(\mathrm{II})$ and traces of $\mathrm{Zn}(\mathrm{II}), \mathrm{Cu}(\mathrm{II})$, $\mathrm{Mg}$ (II) and iron ions (Gotfryd 2006). High purity product can be obtained by removal of all impurities from the crude product. However, recovery of these impurities, i.e. Co(II), $\mathrm{Cu}(\mathrm{II})$ and $\mathrm{Zn}$ (II) from the wastewater, the CNS solution, coming from one of the biggest Polish companies (copper electrorefinery), seems to be a required and prospective industrial solution that fits the definition of cleaner 
technology as it "approaches to manufacturing that minimize the generation of harmful waste and maximize the efficiency of energy use and material use" (Markusson 2011). On the one hand, the recovery of metal ions from CNS is important because of reduction of environmental risk of release of toxic heavy metals to water or soil, while on the other hand, the application of by-product as a secondary source of valuable (the so called "strategic") metals is in accordance with the idea of sustainable development.

For many years, multistage processes have been developed to improve the purification of metal-containing streams. They are based mainly on precipitation of metal hydroxides by calcium or barium compounds and $\mathrm{pH}$ changes. There are some patents that describe formation of pure nickel sulphate by fractional precipitation of other impurities (Drag et al. 1989; Kerfoot et al. 2002; Moritomo et al. 2014). However, the main drawback of the procedure is only partial removal of impurities and formation of iron hydroxide contaminated with significant amounts of barium and calcium sulphates.

Although some authors have proposed the removal of heavy metals from industrial wastewater (Mishra et al. 2014; Zinicovscaia et al. 2015) or sewage (Al-Gheethi et al. 2015) by biosorption on microalgae Spirulina platensisthese or various bacteria, these methods are rather suitable for diluted solutions. In addition, those authors have focused on the removal but not on the recovery of the heavy metals that can be also valuable products. Sulphate solutions containing $\mathrm{Zn}$ (II), $\mathrm{Fe}$ (II), $\mathrm{Cu}$ (II) and $\mathrm{Co}(\mathrm{II})$ can be processed also with multistage solvent extraction to separate pure $\mathrm{NiSO}_{4}$ from sulphate contaminants. Some authors have proposed to obtain a purified nickel sulphate solution using extraction of nickel from CNS by stripping the nickel-loaded organic phase containing derivatives of phosphinic acid. However, the application of acidic extractant required neutralization of the aqueous phase to control the $\mathrm{pH}$ of the extraction system. Otherwise extraction efficiency of $\mathrm{Co}$ (II) and $\mathrm{Zn}$ (II) decreased dramatically (Gotfryd 2006).

One of the most frequently investigated acidic extractants is Cyanex 272, and its selectivity of cobalt extraction from solutions containing nickel sulphate has been confirmed by many researchers (Cytec Industries Inc. 2008) not only with conventional liquid-liquid extraction (Ritcey 2006; Sole et al. 2005) but also with use of liquid membranes (Parhi and Sarangi 2008). However, such acidic extractants as Cyanex 272 (Kang et al. 2010; Zhu et al. 2011), Cyanex 301, Cyanex 302 (Sole and Hiskey 1995) and DEHPA (Kongolo et al. 2003; Van de Voorde et al. 2006) can be successfully replaced by their sodium salts to extract $\mathrm{Ni}(\mathrm{II})$ and $\mathrm{Co}(\mathrm{II})$ from various aqueous solutions (Devi et al. 1994, 1998). Devi et al. (1994, 1997, 1998) have studied sodium salts of DEHPA, PC-88 (2-ethylhexylphosphonic acid mono-2-ethylhexyl ester) and Cyanex 272 for extraction of $\mathrm{Co}(\mathrm{II}), \mathrm{Ni}$ (II) and $\mathrm{Zn}$ (II) from model sulphate solutions. On the basis of their research, the authors indicated Na-Cyanex 272 as the best $\mathrm{Co}$ (II) extractant from among the extractants studied. Reddy and Park (2007) have proposed a flowsheet of the process aimed at separation of cobalt and nickel from copper sulphate solutions with partly saponified Cyanex 272 and D2EHPA and reported almost $100 \%$ of overall recovery of these metals. On the other hand, Sarangi et al. (1999) have investigated chloride solutions of $\mathrm{Co}$ (II) and $\mathrm{Ni}$ (II) and noted that increasing Na-Cyanex 272 concentration caused a decrease in the extraction of both metals. The mechanism by which metal ions are transported from the aqueous phase into the organic phase with partially saponified NaCyanex 272 is as follows (Kang et al. 2010):

$\mathrm{M}_{(\mathrm{aq})}^{2+}+\mathrm{A}_{(\mathrm{org})}^{-}+2(\mathrm{HA})_{2(\mathrm{org})} \Leftrightarrow \mathrm{MA}_{2} \cdot 3 \mathrm{HA}_{(\mathrm{org})}+\mathrm{H}_{(\mathrm{aq})}^{+}$.

On comparing the effects of the use of acidic Cyanex 272 to those of its sodium salt (Na-Cyanex 272), some advantages of the salt application can be indicated: improvement in the efficiency in the initial $\mathrm{pH}$ range between 2.6 and 7 (Devi et al. 1994), the presence of only monomeric form of the extractant (acidic extractant forms dimers resulting in reduction in extraction efficiency). Summarizing, the application of Cyanex 272 salt may improve extraction of divalent metal ions from sulphate secondary sources.

Thus, the paper aimed at carrying out the investigation of the removals of $\mathrm{Co}(\mathrm{II})$ and $\mathrm{Zn}$ (II) from the model and the real sulphate solutions by extraction with sodium bis(2,4,4-trimethylpentyl)phosphinate (Na-Cyanex 272), and comparing the results with those obtained by extraction with acidic Cyanex 272. To the best of our knowledge, the literature data on the use of sodium salts of acidic extractants do not refer to the treatment of real leaching solutions. Extraction of the required compounds from the real solutions generates problems often impossible to predict during the investigation step of model solution, resulting from interactions of ions co-existing in a real mixture. Thus, the novelty of the research presented in this paper is the study of extraction with sodium salt of Cyanex 272 from a real solution after leaching of CNS. The following issues are investigated: (i) the effect of initial $\mathrm{pH}$ of feeds on the extraction efficiency, (ii) leaching of metal ions from CNS, (iii) efficiency and selectivity of the extraction of metal ions from real CNS, and (iv) FT-IR analysis of the structure of complexes formed by the metal ions with the extractant studied. 


\section{Experimental}

\section{Reagents}

Cyanex 272 (bis(2,4,4-trimethylpentyl)phosphinic acid) supplied by Cytec Industries Inc. (2008) was used without further purification. The organic phase containing $0.2 \mathrm{~mol} \mathrm{dm}^{-3}$ Cyanex 272, $1.5 \mathrm{~g} \mathrm{dm}^{-3}$ butylated hydroxytoluene (BHT), and 5 vol\% decan-1-ol in Exxsol D80 (mixture of aliphatic hydrocarbons and cycloparaffins, with aromatics content less than $0.2 \mathrm{wt} \%$, supplied by Brenntag, Poland) was prepared. Some amount of the organic phase was reacted with $2.5 \mathrm{~mol} \mathrm{dm}{ }^{-3} \mathrm{NaOH}(\mathrm{o} / \mathrm{w}=1)$ to convert Cyanex 272 into its sodium salt (Na-Cyanex 272).

Aqueous feeds used for the determination of $\mathrm{pH}$ influence on the extraction contained about $5 \mathrm{~g} \mathrm{dm}^{-3} \mathrm{Co}(\mathrm{II})$ or $\mathrm{Zn}$ (II) (as sulphates, POCh, Poland) and their initial $\mathrm{pH}$ was adjusted with $\mathrm{H}_{2} \mathrm{SO}_{4}$ or $\mathrm{NaOH}$ (POCh, Poland). All chemicals were used as delivered without any purification.

\section{Preparation of Na-Cyanex 272}

Prior to extraction, the organic phase $\left(0.2 \mathrm{~mol} \mathrm{dm}^{-3}\right.$ Cyanex 272, $1.5 \mathrm{~g} \mathrm{dm}^{-3}$ BHT, and 5 vol\% decan-1-ol in Exxsol D80) was conditioned with $2.5 \mathrm{~mol} \mathrm{dm}^{-3} \mathrm{NaOH}$ $(\mathrm{o} / \mathrm{w}=1)$ according to the following reaction: mechanically shaken with the organic phase (volume ratio w/o = 1) for $30 \mathrm{~min}$ at $20^{\circ} \mathrm{C}$ in glass separatory funnels, and then allowed to stand for phase separation. The initial $\mathrm{pH}$ was adjusted in the range of 2-4 with $\mathrm{H}_{2} \mathrm{SO}_{4}$ or $\mathrm{NaOH}$. Stripping was carried out with $2 \mathrm{~mol} \mathrm{dm}^{-3} \mathrm{H}_{2} \mathrm{SO}_{4}$.

Three-stage extraction of metal ions from the CNS leach solution containing 28, 0.69, 0.62 and $0.57 \mathrm{~g} \mathrm{dm}^{-3} \mathrm{Ni}$ (II), $\mathrm{Cu}(\mathrm{II}), \mathrm{Co}(\mathrm{II})$, and $\mathrm{Zn}$ (II) (resulting from the leaching with hot water), $\mathrm{pH} \mathrm{4,} \mathrm{was} \mathrm{carried} \mathrm{out} \mathrm{cross-currently} \mathrm{at} \mathrm{the}$ volume ratio $\mathrm{w} / \mathrm{o}=1$. It means that a raffinate from one stage of extraction was used as a feed in a consecutive extraction stage and made to come into contact for $30 \mathrm{~min}$ with the fresh organic phase as shown in Fig. 1. The organic phase was stripped with $2 \mathrm{~mol} \mathrm{dm}^{-3} \mathrm{H}_{2} \mathrm{SO}_{4}$ (volume ratio $\mathrm{w} / \mathrm{o}=1$ ).

Equilibrium $\mathrm{pH}$ of the aqueous phases after extraction was measured, and metal ion concentration was determined by voltamperommetric method at Computrace VA 727 (Metrohm) (Metrohm 2015a, b).

$\mathrm{Ni}(\mathrm{II}), \mathrm{Co}(\mathrm{II}), \mathrm{Zn}$ (II) and $\mathrm{Cu}(\mathrm{II})$ concentrations in CNS were determined with ICP OES (IRIS, Thermo Jarell Ash, USA) at 224.7, 228.6, 237.8, 221.6, 231.6 and $213.8 \mathrm{~nm}$ for $\mathrm{Cu}, \mathrm{Co}, \mathrm{Co}, \mathrm{Ni}, \mathrm{Ni}$ and $\mathrm{Zn}$, respectively.

The voltamperommetric and ICP measurements were replicated three times.

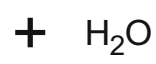

Sodium salt of Cyanex 272 exists mainly as a monomer, while acidic extractant (HA) forms dimers according to the reaction (Rydberg et al. 2004):

$2(\mathrm{HA})_{(\text {org })} \Leftrightarrow \mathrm{H}_{2} \mathrm{~A}_{2(\mathrm{org})}$.

Both forms can act as extractants, however, they differ in the mechanism of extraction (Devi et al. 1994).

The degree of neutralization of Na-Cyanex 272 used in this work was calculated from the mass balance of $\mathrm{OH}^{-}$determined before and after neutralization and was equal to almost $100 \%\left(0.196 \mathrm{~mol} \mathrm{dm}^{-3}\right)$. It is assumed that the difference in $\mathrm{OH}^{-}$in the aqueous phases refers to $\mathrm{Na}^{+}$transferred into the organic phase to form sodium salt of Cyanex 272.

\section{Extraction procedure}

Extraction was carried out in a typical way: aqueous feeds containing $5 \mathrm{~g} \mathrm{dm}^{-3}$ of $\mathrm{Co}(\mathrm{II})$ or $\mathrm{Zn}(\mathrm{II})$ sulphate were

\section{Leaching of crude nickel sulphate solution}

CNS originated from three Polish smelters: Glogow I HM, Glogow II HM and Legnica HM. The CNS was dissolved in hot demineralized water $\left(60,70,80\right.$ and $\left.90^{\circ} \mathrm{C}\right)$ and mixed for $3 \mathrm{~h}(1200 \mathrm{rpm})$ using a magnetic stirrer upon heating (RCT basic IKA). This process was accompanied by a decrease in $\mathrm{pH}$ from 1.8 to 1.02 . After cooling, the neutralizing agent $\left(1 \mathrm{~mol} \mathrm{dm}^{-3} \mathrm{NaOH}\right)$ was added to obtain $\mathrm{pH}$ of nearly 4.5 . Then, the solutions prepared were stirred over the same operating parameters and temperatures for $2 \mathrm{~h}$. As a result of oxyhydrolysis, a partial precipitation of the impurities such as iron, arsenic, antimony, some aluminium, calcium and lead took place. In the next step, the phases were separated by sedimentation at the low temperature and filtration at the high one. Measurements of $\mathrm{pH}$ values of the aqueous solution carried out before leaching of CNS and after its dissolution were considered 
Fig. 1 Schematic representation of the three-stage extraction

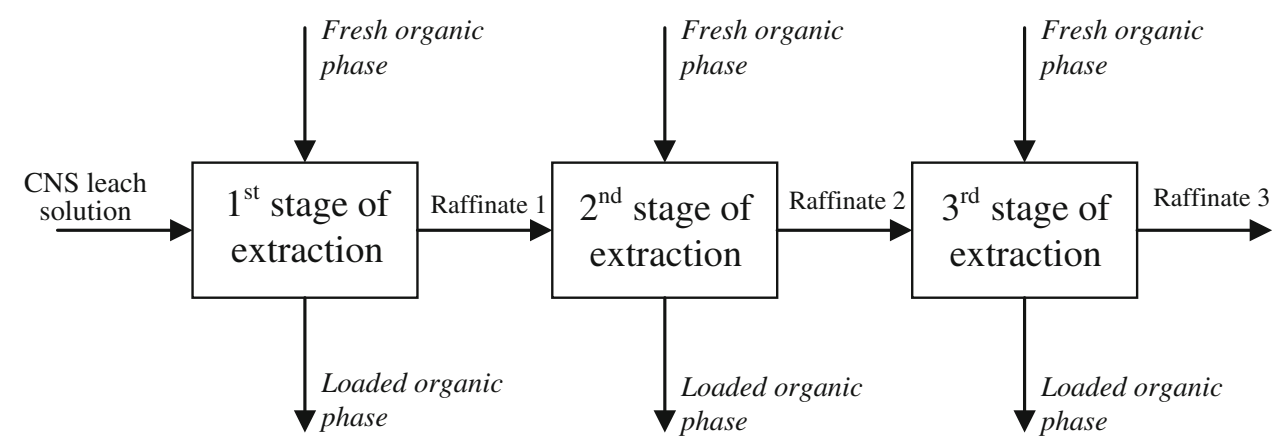

as reliable when $\mathrm{pH}$ values changed by less than 0.1 within a time period of $10 \mathrm{~min}$.

\section{Synthesis of organic complexes}

The laboratory synthesis of complexes of $\mathrm{Co}$ (II) or $\mathrm{Zn}$ (II) with Cyanex 272 and Na-Cyanex 272 was carried out in the following way: the solution of $\mathrm{Co}$ (II) and $\mathrm{Zn}$ (II) sulphates in ethanol was heated under reflux until complete dissolution. Then, the solution of extractant in ethanol was added (molar ratio metal:extractant $1: 1$ or $1: 2$ ), and the resulting mixture was boiled under reflux for $3 \mathrm{~h}$. The precipitates were filtered off and next washed with ethanol. The yields were for the complex Co:extractant 1:1 $76 \%$ (m.p. $\quad 69.1-71.9^{\circ} \mathrm{C}$ ), Co:extractant $1: 2 \quad 71 \%$ (m.p. 41.8-43.1 and next 71.7-73.1 $\left.{ }^{\circ} \mathrm{C}\right), \mathrm{Zn}$ :extractant $1: 149 \%$ (m.p. $29.1-30.4{ }^{\circ} \mathrm{C}$ ) and $\mathrm{Zn}$ :extractant $1: 262 \%$ (m.p. 25.4-27.9 $\left.{ }^{\circ} \mathrm{C}\right)$.

The synthesis of Na-Cyanex 272 was carried out using ethanol as a diluent. The mixture of Cyanex 272 and $\mathrm{NaHCO}_{3}$ was boiled under reflux for $6 \mathrm{~h}$. Both mixtures were left to cool to room temperature. After that, the diluent was evaporated under vacuum, dried and washed with chloroform. The white precipitate was recrystallized from ethanol and isolated with $89.5 \%$ yield, m.p. 243.1-249.9 ${ }^{\circ} \mathrm{C}$.

\section{Spectroscopic analysis}

FT-IR analyses of the organic phases obtained from extraction and stripping were carried out on the Vertex 70 Spectrometer (Bruker Optics FT-IR) in the range of IR $400-4000 \mathrm{~cm}^{-1}$. The spectra of the organic phases were recorded using $\mathrm{KBr}$ liquid transmission cells or as thin films using $\mathrm{NaCl}$ discs (plates). Spectra of the complexes synthesized, as well as, of the Na-Cyanex 272 were recorded in the range of IR $500-4000 \mathrm{~cm}^{-1}$ using the Vertex 70 Spectrometer equipped with a MIRacle ${ }^{\mathrm{TM}}$ ATR accessory (single reflection diamond ATR crystal).

\section{Calculations}

Distribution ratio of metal ions $\left(D_{M}\right)$ was defined as

$D_{M}=\frac{C_{M}^{\mathrm{org}}}{C_{M}^{\mathrm{aq}}}$,

where $C_{M}^{\mathrm{org}}$ and $C_{M}^{\mathrm{aq}}$ stand for the concentrations of metal ions after extraction in the organic and aqueous phases, respectively.

Percentage extraction $(E)$ was calculated from the contents of metal ions in the aqueous phases before $m_{M}^{0}$ and after $m_{M}^{\mathrm{aq}}$ extraction:

$E=\frac{m_{M}^{0}-m_{M}^{\mathrm{aq}}}{m_{M}^{0}} \times 100 \%$.

The total percentage extraction $\left(\sum E\right)$ for the three-stage extraction was calculated as follows:

$\sum E=\frac{\sum m_{M}^{\mathrm{org}}}{m_{M}^{0}}$.

Selectivity of metal ion extraction was characterized by separation coefficient, $\beta_{M 1 / M 2}$, defined as

$\beta_{M 1 / M 2}=\frac{D_{M 1}}{D_{M 2}}$,

where $D_{M 1}$ and $D_{M 2}$ denote distribution ratios of respective metals in a mixture.

\section{Results and discussion}

\section{Extraction with Na-Cyanex 272 and Cyanex 272}

The extractions of $\mathrm{Co}(\mathrm{II})$ and $\mathrm{Zn}(\mathrm{II})$ with solutions of Cyanex 272 and Na-Cyanex 272 from model aqueous solutions at the initial metal concentration of $5 \mathrm{~g} \mathrm{dm}^{-3}$ yielded the results as presented in Figs. 2 and 3.

Extraction of Co(II) with Na-Cyanex 272 is efficient and amounts to over $90 \%$ in the range of the initial $\mathrm{pH}\left(\mathrm{pH}_{\mathrm{ini}}\right)$ values studied (Fig. 2). The efficiency of $\mathrm{Co}$ (II) extraction is much higher at the initial $\mathrm{pH}$ lower than that reported by 


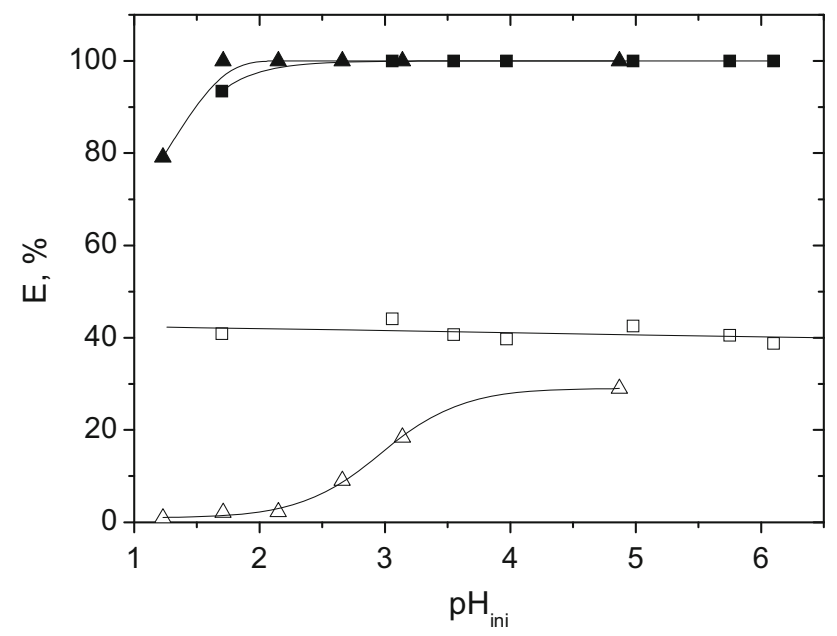

Fig. 2 Influence of the initial $\mathrm{pH}$ on extractions of $\mathrm{Co}(\mathrm{II})$ (black square, white square) and $\mathrm{Zn}$ (II) (black triangle, white triangle) with Na-Cyanex 272 (black square, black triangle) and Cyanex 272 (white square, white triangle)

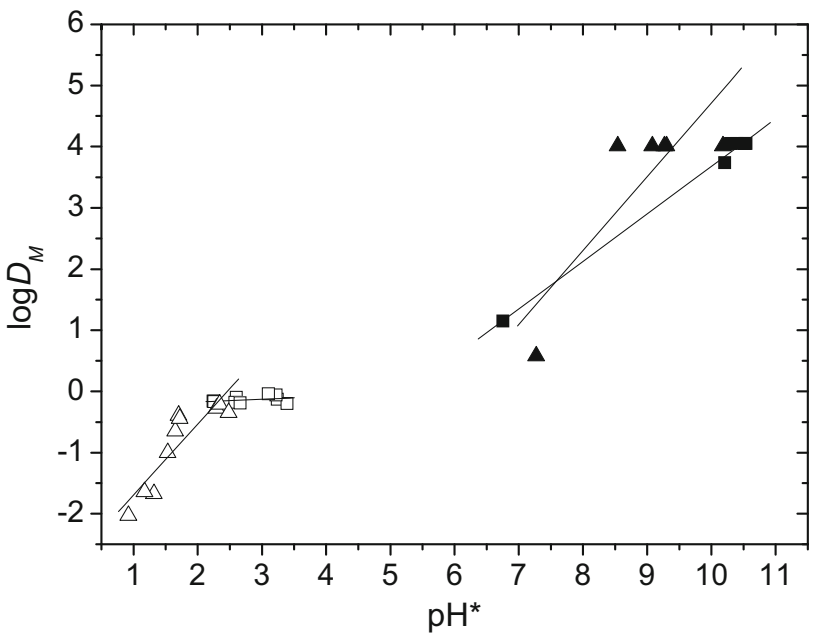

Fig. 3 Dependence of $\log D_{M}$ on equilibrium $\mathrm{pH}$ of the aqueous phase after extraction of $\mathrm{Co}(\mathrm{II})$ (black square, white square) and $\mathrm{Zn}(\mathrm{II})$ (black triangle, white triangle) with Na-Cyanex 272 (black square, black triangle) and Cyanex 272 (white square, white triangle)

Devi et al. $(1994,1998)$ who investigated Co(II) extraction also with Na-Cyanex 272. However, the difference between their results and ours stems from different concentrations of metal ions in the feed and also in the degree of neutralization of Cyanex 272. In Devi et al.'s works, Cyanex 272 was not fully saponified which affected the extraction behaviour of the organic phase.

Extraction of $\mathrm{Zn}(\mathrm{II})$ at $\mathrm{pH} 1$ equals $80 \%$, and increases to a constant value of $100 \%$ when $\mathrm{pH}$ is increased. The $\mathrm{pH}$ change does not affect significantly the percentage extraction; thus, in the case of Na-Cyanex 272, the initial $\mathrm{pH}$ does not have to be strictly controlled. It is important to maintain $\mathrm{pH}$ below 6.5 to avoid precipitation of metal ion hydroxides.
To compare the efficiencies of $\mathrm{Co}(\mathrm{II})$ and $\mathrm{Zn}(\mathrm{II})$ extractions with Cyanex 272 salt and the acidic form of the extractant, one-stage extraction was carried out. The percentage extractions of $\mathrm{Co}$ (II) and $\mathrm{Zn}$ (II) with the acidic Cyanex 272, shown in Fig. 2, are lowered to half of that when compared with its sodium salt. This phenomenon can be explained by the formation of dimers of organophosphoric acid resulting from hydrogen bond interactions between the molecules of the organic acid, as shown in Fig. 4 (Rydberg et al. 2004).

Therefore, the lower the content of acidic form, the lower the number of dimers in the organic phase. As observed from Eq. (1), only partial saponification of the acidic form causes that for each extracted metal ion even five molecules of the extractant are used, while for the extraction with sodium salt of Cyanex 272, it proceeds with two molecules of an extractant according to the following reaction:

$2 \mathrm{R}_{2} \mathrm{P}(\mathrm{O}) \mathrm{ONa}_{(\text {org })}+\mathrm{M}_{(a q)}^{2+} \Leftrightarrow\left[\mathrm{R}_{2} \mathrm{P}(\mathrm{O}) \mathrm{O}_{2} \mathrm{M}_{(\text {org })}+2 \mathrm{Na}_{(\mathrm{aq})}^{+}\right.$.

As a consequence, higher percentage extraction of metal ions is reported for the extraction with sodium salt than with acidic Cyanex 272 (Figs. 2, 3). Co(II) extraction with Cyanex 272 is at a constant level, i.e. $40-50 \%$, for $\mathrm{pH}$ from the range studied. Zn(II) extraction with Cyanex 272 increases with the increasing $\mathrm{pH}$, and over $\mathrm{pH} 3$, it is constant and equals $30 \%$. Na-Cyanex 272 performs much better in the extractions of $\mathrm{Co}$ (II) and $\mathrm{Zn}$ (II) $\left(\log D_{M}\right.$ close to 4) than does the acidic form of Cyanex $272\left(\log D_{M}\right.$ as maximum amounts to 0 ). Figure 3 confirms that, as a result of $\mathrm{Co}(\mathrm{II})$ and $\mathrm{Zn}$ (II) extractions with Na-Cyanex 272, the equilibrium $\mathrm{pH}$ is shifted to higher $\mathrm{pH}$ values because there is no proton release to the aqueous phase. This observation confirms full conversion of Cyanex 272 into its sodium salt before extraction.

\section{Effect of metal ion extraction on $\mathrm{pH}$ of the aqueous phase}

Changes in the equilibrium $\mathrm{pH}$ of the aqueous phase as a consequence of metal ion extraction with solutions of Cyanex 272 or Na-Cyanex 272 are shown in Fig. 5.

Equilibrium $\mathrm{pH}$ of the raffinate after extraction with salt of Cyanex 272 increases significantly to $\mathrm{pH} \mathrm{10,} \mathrm{and} \mathrm{does}$

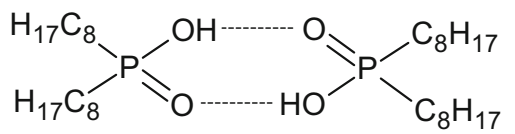

Fig. 4 Dimeric form of bis(2,4,4-trimethylpentyl)phosphinic acid (Cyanex 272) 


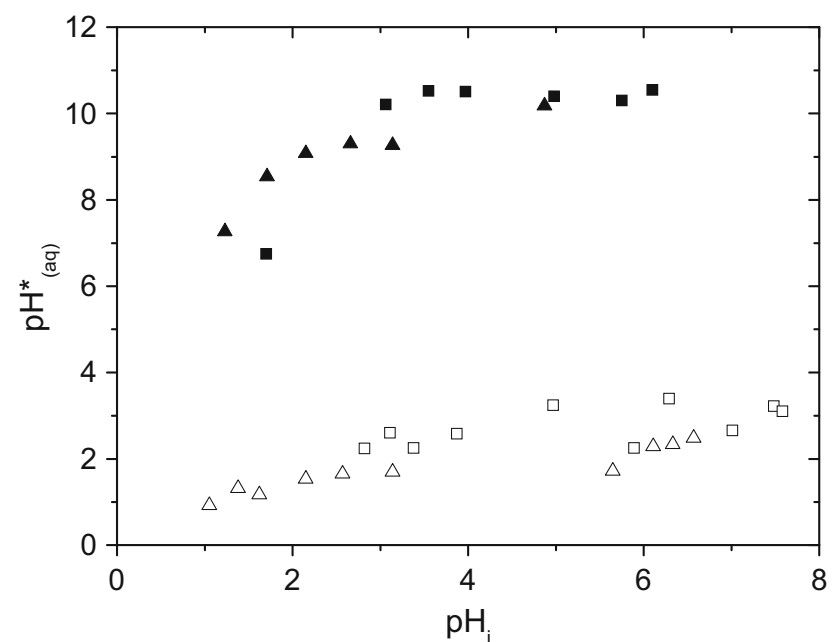

Fig. 5 Changes in equilibrium $\mathrm{pH}\left(\mathrm{pH}^{*}{ }_{(\mathrm{aq})}\right)$ for various initial $\mathrm{pH}$ values of the feed after extraction of $\mathrm{Co}$ (II) (black square, white square) and $\mathrm{Zn}(\mathrm{II})$ (black triangle, white triangle) with Na-Cyanex 272 (black square, black triangle) and Cyanex 272 (white square, white triangle)

not depend on the initial pH (Fig. 5). The reason for this drastic $\mathrm{pH}$ change can be explained by $\mathrm{Na}^{+}$exchange from Na-Cyanex 272 into ions of the metal extracted (Kang et al. 2010). Most possibly, the excess of the sodium salt undergoes hydrolysis to be converted into the acidic form of the extractant, resulting in the formation of sodium hydroxide in the aqueous phase. The reaction of the process has been proposed in an earlier work of the authors (Staszak et al. 2012). On the contrary, pH values after extraction with acidic Cyanex 272 decrease as a result of proton transfer from acidic extractant in the organic phase to the aqueous phase and simultaneous extraction of $\mathrm{Co}$ (II) or $\mathrm{Zn}(\mathrm{II})$ to the organic phase.

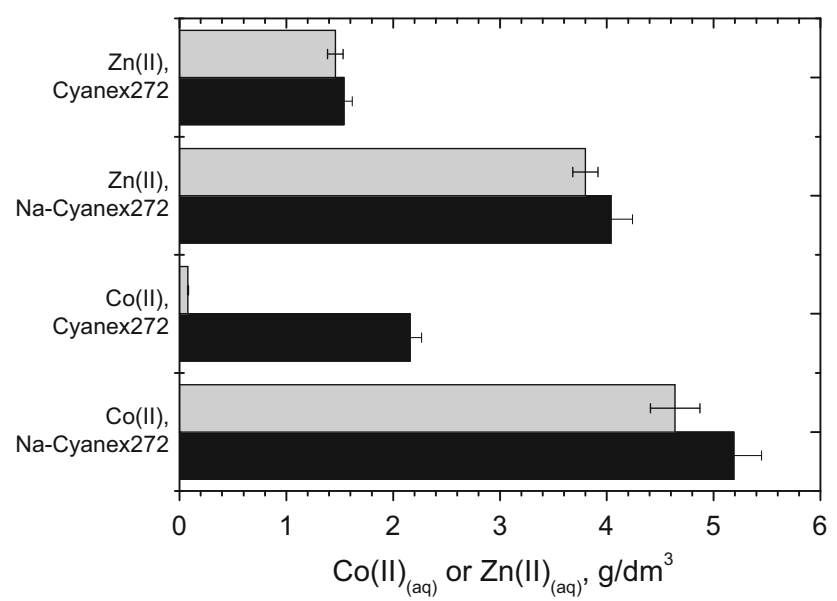

Fig. $6 \mathrm{Co}(\mathrm{II})$ or $\mathrm{Zn}(\mathrm{II})$ content in the extract (black square) or strippant (grey square)

\section{Stripping of Co(II) and $\mathrm{Zn}$ (II) from the organic phases}

Stripping of both metal ions from the extracts (the organic phases) was carried out with $2 \mathrm{~mol} \mathrm{dm}^{-3}$ solution of $\mathrm{H}_{2} \mathrm{SO}_{4}$, and the efficiency of $\mathrm{Co}(\mathrm{II})$ or $\mathrm{Zn}(\mathrm{II})$ stripping is shown in Fig. 6.

The Co(II) and $\mathrm{Zn}$ (II) stripping from Na-Cyanex 272 organic phase is efficient and attains $80-90 \%$ efficiency of stripping of the metal ions. Co(II) stripping from acidic Cyanex 272 almost does not occur $(2-3 \%)$. On the contrary, $\mathrm{Zn}(\mathrm{II})$ is stripped from Cyanex 272 very effectively, to reach almost $100 \%$. As the stripping runs according to the following reaction,

$$
\left[\mathrm{R}_{2} \mathrm{P}(\mathrm{O}) \mathrm{O}\right]_{2} \mathrm{M}_{(\mathrm{org})}+2 \mathrm{H}_{(a q)}^{+} \Leftrightarrow 2 \mathrm{R}_{2} \mathrm{P}(\mathrm{O}) \mathrm{OH}_{(\mathrm{org})}+\mathrm{M}_{(\mathrm{aq})}^{2+} \text {, }
$$

the acidic form of the extractant is obtained as a result of stripping, regardless of the original form of Cyanex 272 before extraction.

\section{Extractions of $\mathrm{Co}(\mathrm{II})$ and $\mathrm{Zn}(\mathrm{II})$ from their mixture}

As the next step, to investigate separation of both metal ions, extractions of $\mathrm{Co}(\mathrm{II})$ and $\mathrm{Zn}$ (II) were carried out from the sulphate solution containing about $0.1 \mathrm{~mol} \mathrm{dm}^{-3}$ of each metal ion, i.e. 5.6 and $5.7 \mathrm{~g} \mathrm{dm}^{-3}$ of $\mathrm{Co}$ (II) and $\mathrm{Zn}(\mathrm{II})$, respectively, $\mathrm{pH} 4$.

The results shown in Fig. 7 evidence that $\mathrm{Zn}$ (II) is almost quantitatively extracted (96\%) to the organic phase containing Na-Cyanex 272, while almost half of $\mathrm{Co}(\mathrm{II})$ remains in the aqueous solution. Selectivity coefficient of $\mathrm{Zn}$ (II) extraction in the presence of $\mathrm{Co}(\mathrm{II})$ is equal to almost 25 . On the one hand, it means that the majority of

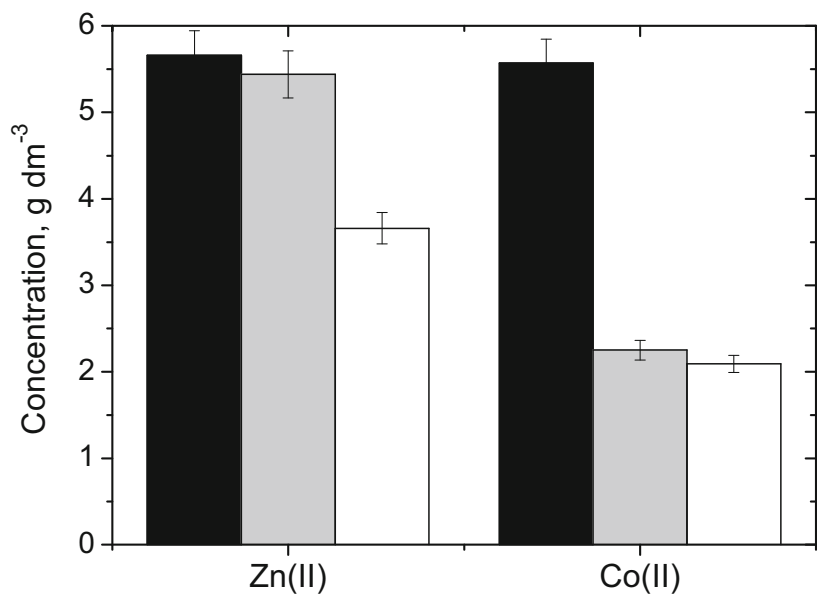

Fig. 7 Comparison of $\mathrm{Co}(\mathrm{II})$ and $\mathrm{Zn}$ (II) concentrations in the feed (black square), organic (extract) (grey square) and stripping phase (white square) (organic phase: Na-Cyanex 272) 
$\mathrm{Zn}(\mathrm{II})$ is transported to the organic phase, but it cannot be selectively separated from Co(II). On the other hand, almost $50 \%$ of $\mathrm{Co}$ (II) that remained in the aqueous solution is almost completely free from $\mathrm{Zn}$ (II).

\section{Crude nickel sulphate}

\section{Leaching of crude nickel sulphate}

Finally, extraction of metal ions from real CNS solution was investigated. Solid CNS was leached according to the procedure described in the Experimental section to obtain solution containing metal ions for further extraction. At first, CNS was mixed with water, and the colour was observed to change from dull greyish green to clear dark green. This operation resulted in separation of the insoluble residues. The resulting green colour of the solution indicated the high concentration of nickel ions in the solution.

Table 1 shows the $\mathrm{pH}$ values of the aqueous solution measured before leaching of CNS and after its dissolution at the four temperatures analysed. Regardless of the leaching temperature, a decrease in $\mathrm{pH}$ of the solution is observed. These $\mathrm{pH}$ changes are caused by leaching of metal sulphates present in the CNS supplied from the foundry to the aqueous phase.

After each leaching experiment, the mass of sediment was measured (Table 1, the initial amount of CNS was $20 \mathrm{~g})$. It was noted that the mass decreases with the increasing temperature during the process. This shows a much better leaching of metal salts from CNS at high temperatures.

As a result of the leaching, the following concentrations of metal ions were obtained: 28, 0.69, 0.62 and $0.57 \mathrm{~g} \mathrm{dm}^{-3}$ of $\mathrm{Ni}(\mathrm{II}), \mathrm{Cu}(\mathrm{II}), \mathrm{Co}(\mathrm{II})$ and $\mathrm{Zn}(\mathrm{II})$, respectively.

\section{Extraction of metal ions from CNS solution}

The focus was on the extractive technique used for the recovery of the metal ions present in CNS in three consecutive stages of extraction with the organic phase containing $0.2 \mathrm{~mol} \mathrm{dm}^{-3}$ Na-Cyanex 272, $1.5 \mathrm{~g} \mathrm{dm}^{-3}$ BHT and 5 vol\% decan-1-ol in Exxsol D80. The $\mathrm{pH}$ value of the

Table $1 \mathrm{pH}$ of the aqueous samples at the beginning and at the end of mixing (initial and final $\mathrm{pH}$ ) for the first stage of CNS leaching and mass of sediment left $(m)$

\begin{tabular}{llll}
\hline$T\left({ }^{\circ} \mathrm{C}\right)$ & Initial $\mathrm{pH}$ & Final $\mathrm{pH}$ & $m, \mathrm{~g}$ \\
\hline 60 & 1.8 & 1.02 & 4.17 \\
70 & 1.8 & 0.98 & 4.33 \\
80 & 1.8 & 1.07 & 3.69 \\
90 & 1.8 & 1.06 & 2.55 \\
\hline
\end{tabular}

feed containing 28, 0.69, 0.62 and $0.57 \mathrm{~g} \mathrm{dm}^{-3} \mathrm{Ni}(\mathrm{II})$, $\mathrm{Cu}(\mathrm{II}), \mathrm{Co}(\mathrm{II}), \mathrm{Zn}$ (II) (obtained from the leaching with hot water at $60^{\circ} \mathrm{C}$ ) was initially established as 4 . After the first and second stages of extraction with Na-Cyanex 272, the $\mathrm{pH}$ increased up to 6.7 and 6.9 , while after the third stage, it decreased to 4.8. One-step stripping of the metal ions from the organic phase after the first and the second extraction stages was carried out using $2 \mathrm{~mol} \mathrm{dm}^{-3} \mathrm{H}_{2} \mathrm{SO}_{4}$.

The results of three-stage extraction are presented in two separate figures (Figs. 8, 9) because of large difference in the concentrations of $\mathrm{Ni}(\mathrm{II})$ and the other metals.

In each consecutive stage, the $\mathrm{Ni}(\mathrm{II})$ concentration in the aqueous phase decreased, and the total percentage of extraction after three stages was equal to $76 \%$. However, the three stages were not enough to deplete it completely; still nearly $8 \mathrm{~g} \mathrm{dm}^{-3}$ of $\mathrm{Ni}(\mathrm{II})$ remained in the aqueous phase (Fig. 8). In the mean time, $\mathrm{Cu}$ (II) and $\mathrm{Co}$ (II) were fully extracted with $0.2 \mathrm{~mol} \mathrm{dm}^{-3}$ Na-Cyanex 272 (Fig. 9). After stage one of extraction, copper(II) is almost completely removed, while the least extraction efficiency is noted for $\mathrm{Zn}$ (II). However, Zn(II) percentage extraction after the three stages is high enough to reach almost $90 \%$.

Stripping of $\mathrm{Zn}(\mathrm{II}), \mathrm{Co}(\mathrm{II})$ and $\mathrm{Cu}(\mathrm{II})$ with $2 \mathrm{~mol} \mathrm{dm}^{-3}$ $\mathrm{H}_{2} \mathrm{SO}_{4}$ is effective, and yields between 40 and near $60 \%$ of the stripped metal ions in stage one (Fig. 10).

\section{Selectivity of extraction of metal ions from CNS solution}

Selectivity of extraction is an important issue to separate various metal ions. Selectivity factors of $\mathrm{Ni}(\mathrm{II})$ over the other metal ions are rather low because of the great amount of excess of $\mathrm{Ni}$ (II) in the aqueous feed (Table 2). Thus, no selective separation of $\mathrm{Ni}(\mathrm{II})$ and the other metals is possible in the presented system.

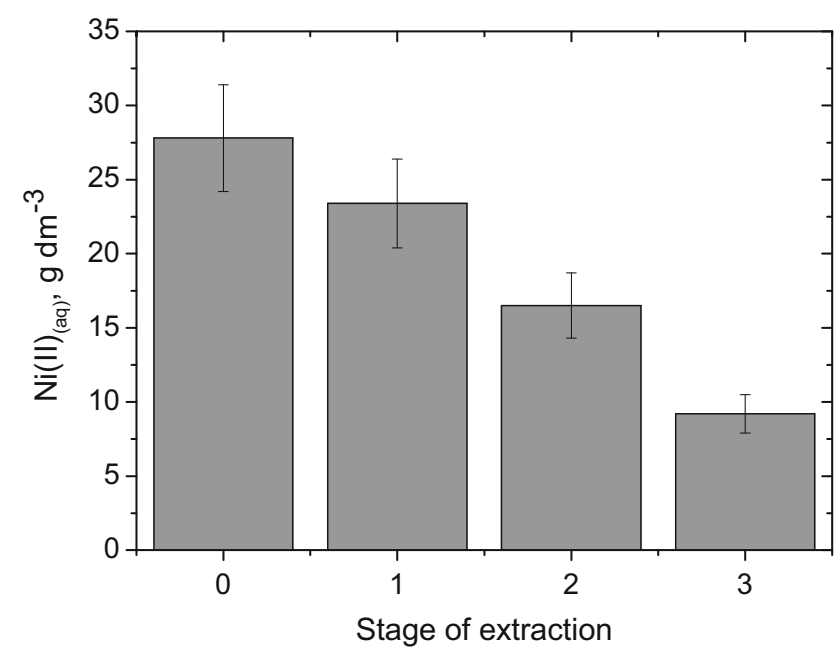

Fig. 8 Concentration of Ni(II) in sulphate mixture: 0 feed, 1 after one stage of extraction, 2 after second stage of extraction, 3 after third stage of extraction; the organic phase: $0.2 \mathrm{~mol} \mathrm{dm}^{-3} \mathrm{Na}-\mathrm{Cyanex} 272$ 


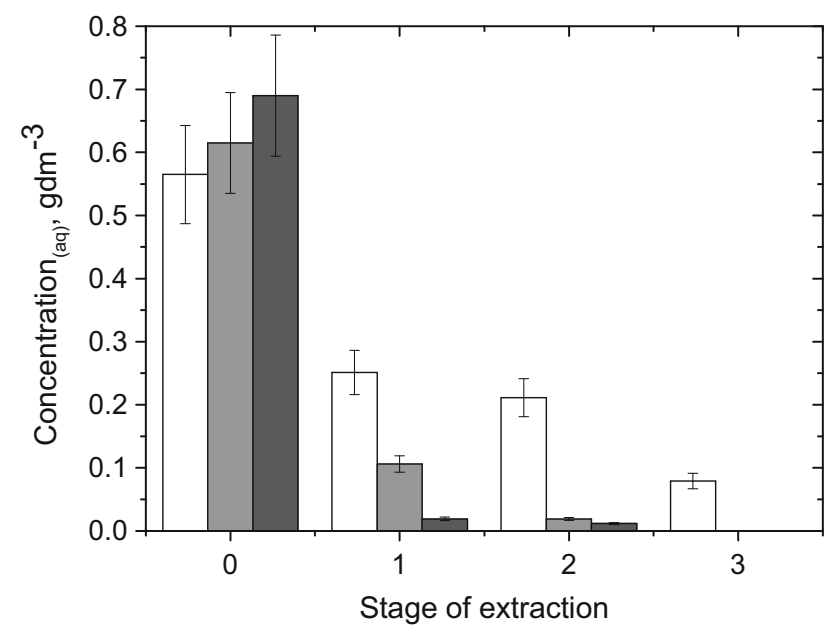

Fig. 9 Concentrations of (white square) $\mathrm{Zn}(\mathrm{II})$, (grey square) $\mathrm{Co}(\mathrm{II})$, and (black square) $\mathrm{Cu}$ (II) in sulphate mixture: 0 feed, 1 after one stage of extraction, 2 after second stage of extraction, and 3 after third stage of extraction; the organic phase: $0.2 \mathrm{~mol} \mathrm{dm}^{-3} \mathrm{Na}-\mathrm{Cyanex} 272$

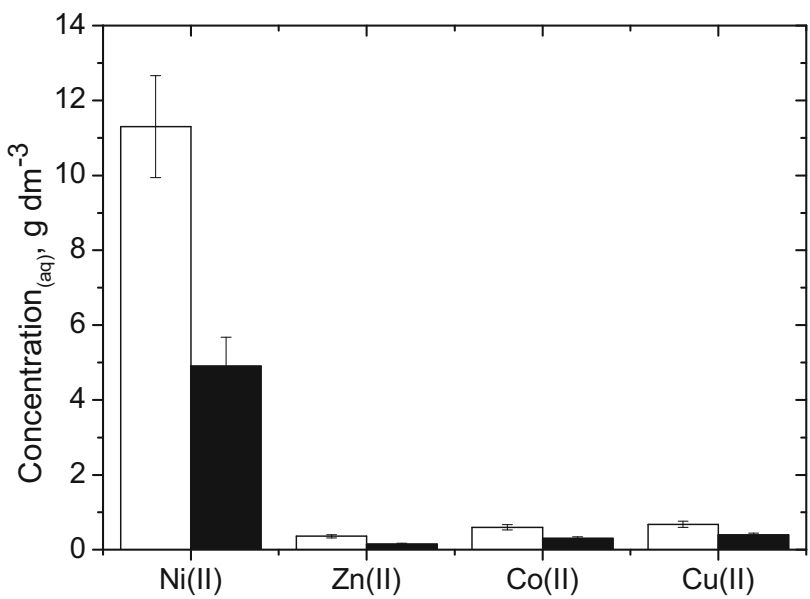

Fig. 10 Stripping of metal ions from the loaded organic phase after the first stage of extraction (white square extracted metal ions, black square stripped metal ions)

Table 2 Selectivity factors of Ni(II) over the other metals in consecutive stages of extraction with $0.2 \mathrm{~mol} \mathrm{dm}^{-3}$ Na-Cyanex 272

\begin{tabular}{llll}
\hline Stage of extraction & $S_{\mathrm{Ni}(\mathrm{II}) / \mathrm{Zn}(\mathrm{II})}$ & $S_{\mathrm{Ni}(\mathrm{II}) / \mathrm{Co}(\mathrm{II})}$ & $S_{\mathrm{Ni}(\mathrm{II}) / \mathrm{Cu}(\mathrm{II})}$ \\
\hline 1 & 0.16 & 0.04 & 0.01 \\
2 & 2.71 & 0.09 & 0.38 \\
3 & 0.49 & 0.01 & 0.01 \\
\hline
\end{tabular}

According to the selectivity factors of $\mathrm{Ni}(\mathrm{II})$ over the other metals, $\mathrm{Ni}(\mathrm{II})$ should be removed from the aqueous mixture prior to the extraction with Na-Cyanex 272. Next, the mixture of $\mathrm{Zn}(\mathrm{II}), \mathrm{Co}(\mathrm{II})$, and $\mathrm{Cu}(\mathrm{II})$ can be processed. Selectivity factors of $\mathrm{Co}$ (II) separation over $\mathrm{Zn}(\mathrm{II})$, presented in Table 3, are high and increase after each
Table 3 Selectivity factors of Co(II) separation over $\mathrm{Zn}$ (II) in consecutive stages of extraction with $0.2 \mathrm{~mol} \mathrm{dm}^{-3} \mathrm{Na}-\mathrm{Cyanex} 272$

\begin{tabular}{llll}
\hline Stage of extraction & $S_{\mathrm{Co}(\mathrm{II}) / \mathrm{Zn}(\mathrm{II})}$ & $S_{\mathrm{Co}(\mathrm{II}) / \mathrm{Cu}(\mathrm{II})}$ & $S_{\mathrm{Zn}(\mathrm{II}) / \mathrm{Cu}(\mathrm{II})}$ \\
\hline 1 & 3.78 & 0.15 & 0.04 \\
2 & 28.0 & 4 & 0.14 \\
3 & 34.5 & 1 & 0.008 \\
\hline
\end{tabular}

extraction stage. Thus, they indicate good separation of $\mathrm{Co}$ (II) from sulphate mixture in the presence of $\mathrm{Zn}$ (II). However, it is important to remove first $\mathrm{Cu}$ (II) because it can be more easily extracted than both $\mathrm{Co}(\mathrm{II})$ and $\mathrm{Zn}$ (II).

\section{FT-IR analysis of the organic phases}

FT-IR analysis was carried out to confirm the results obtained in the study of extraction. The FT-IR spectra of the organic phases containing Cyanex 272 and its sodium salt (Na-Cyanex 272) are shown in Fig. 11.

FT-IR spectrum of Cyanex 272 shows broad bands in the region of phosphinic group with the maxima at 2305 and $1713 \mathrm{~cm}^{-1}$, which correspond to the bonded PO-H (stretching and deformation vibrations, respectively) and very strong bands in the range of $1200-900 \mathrm{~cm}^{-1}$ with the maximum region near $1177 \mathrm{~cm}^{-1}(\mathrm{P}=\mathrm{O}$ stretching band) and at 1055 and $956 \mathrm{~cm}^{-1}$ corresponding to $\mathrm{P}-\mathrm{OH}$ stretching bands. As a result of Cyanex 272 being transferred into its sodium salt, the FT-IR spectra differ especially in the range near $2300 \mathrm{~cm}^{-1}$, where the strong absorption of $\mathrm{O}-\mathrm{H}$ band is markedly reduced. In addition, the absorption peaks in the regions of $\mathrm{P}=\mathrm{O}, \mathrm{PO}-\mathrm{H}$, and $\mathrm{P}-$ $\mathrm{OH}$ vibration bonds upon formation of sodium salts shift from 1178 to $1129 \mathrm{~cm}^{-1}$, from 1713 to $1660 \mathrm{~cm}^{-1}$, and from 956 to $1026 \mathrm{~cm}^{-1}$, respectively. The FT-IR analysis also shows the disappearance of the $\mathrm{O}-\mathrm{P}-\mathrm{O}$ wagging and rocking vibrations initially observed at 566 and $545 \mathrm{~cm}^{-1}$.

The spectra of the organic phases containing Na-Cyanex 272 before and after extraction, and after stripping of individual $\mathrm{Co}(\mathrm{II})$ or $\mathrm{Zn}(\mathrm{II})$ and their mixture, are also studied and shown in Figs. 12 and 13 in Supplementary data.

The FT-IR analysis of the organic phase after $\mathrm{Zn}$ (II) extraction shows further changes in the Cyanex 272 spectra due to the metal chelation: the $\mathrm{P}-\mathrm{O}^{-}$stretching band shifts from 1026 to $1041 \mathrm{~cm}^{-1}, \mathrm{P}=\mathrm{O}$ stretching band shifts from 1129 to $1136 \mathrm{~cm}^{-1}$, and an increase in the intensity of the signal in the $538-546 \mathrm{~cm}^{-1}$ region, which is attributed to $\mathrm{Zn}-\mathrm{O}$ stretching band.

In the case of the extraction of $\mathrm{Co}(\mathrm{II})$, the spectral analysis also shows the changes in the $\mathrm{P}-\mathrm{O}^{-}$and the $\mathrm{P}=\mathrm{O}$ stretching bands, which are shifted to 1041 and $1136 \mathrm{~cm}^{-1}$, respectively. However, the signal at $1041 \mathrm{~cm}^{-1}$ has lower 


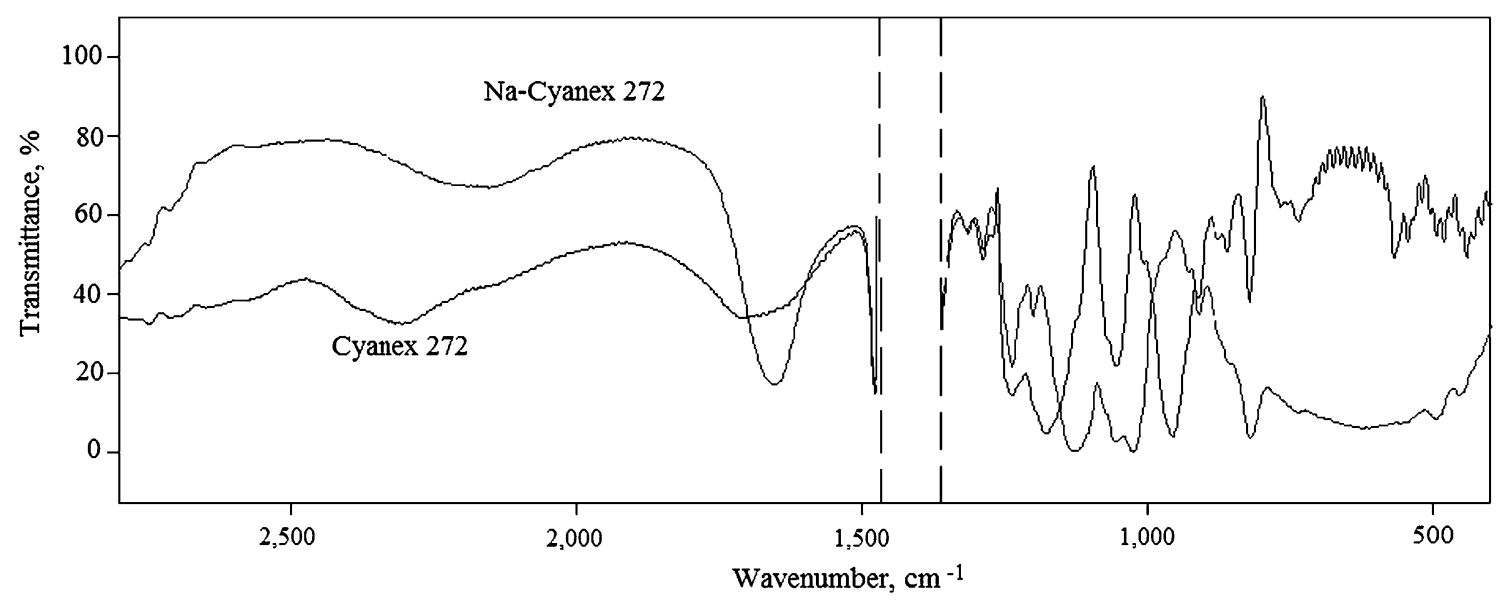

Fig. 11 FT-IR spectra of the organic phases containing acidic form of Cyanex 272 and its sodium salt, Na-Cyanex 272

intensity than that of the corresponding uncomplexed NaCyanex 272. After stripping, the signals being attributed to the changes resulting from the complexation process return to the positions of free Cyanex 272, and this confirms the efficient back extraction of the metals to the aqueous solution. The most characteristic changes noted after stripping are for the band at $1026 \mathrm{~cm}^{-1}$, which is shifted towards lower frequencies $\left(956 \mathrm{~cm}^{-1}\right)$; for the $\mathrm{P}=\mathrm{O}$ stretching bands, the band shifts from $1129 \mathrm{~cm}^{-1}$ to $1177 \mathrm{~cm}^{-1}$; and the appearance of the signals at 545 and $566 \mathrm{~cm}^{-1}$ which are attributed to $\mathrm{O}-\mathrm{P}-\mathrm{O}$ vibrations.

Changes in the FT-IR spectra of the organic phase similar to those shown in Fig. 12 are noted after extraction of both metals from model mixture solution. However, after extraction of metals from CNS, the changes suggest a hydrolysis of Na-Cyanex 272 to the acidic form of Cyanex 272 (Fig. 13b, Supplementary Data).

FT-IR (ATR) spectra of the $\mathrm{Co}(\mathrm{II})$ and $\mathrm{Zn}(\mathrm{II})-\mathrm{Na}-$ Cyanex 272 complexes synthesized at 1:1 and 1:2 molar ratios in comparison with the synthesized Na-Cyanex 272 are shown in Figs. 14 and 15 in Supplementary data. The analysis, as expected, shows characteristic spectral changes resulting from the zinc(II) and cobalt(II) coordination; however, no differences between the complexes synthesized at the Na-Cyanex 272:metal molar ratios of 1:1 and 2:1 were observed. The most characteristic effect confirming zinc(II) complexation is the shift of the signals attributed to the $\mathrm{P}-\mathrm{O}^{-}$and the $\mathrm{P}=\mathrm{O}$ stretching bands observed in the spectral range of $1200-1000 \mathrm{~cm}^{-1}$ (signal observed at 1049 is shifted to $1124 \mathrm{~cm}^{-1}$; that observed at 1057 shifted to $1049 \mathrm{~cm}^{-1}$; and the signal observed at $1028 \mathrm{~cm}^{-1}$ to $1024 \mathrm{~cm}^{-1}$ ). The FT-IR spectra of the loaded organic phase and of the synthesized complexes differ from each other; however, the difference does not result from formation of different complexes but from the presence of BHT and decan-1-ol in the organic phase.
The complexation of cobalt(II) is also combined with the $\mathrm{P}-\mathrm{O}^{-}$and the $\mathrm{P}=\mathrm{O}$ stretching bands changes, but the presented results suggest the difference between the structures of Na-Cyanex 272-cobalt(II) and $\mathrm{Na}$-Cyanex 272-zinc(II) complexes. The most important changes resulting from complexation of cobalt ions with Na-Cyanex 272 is the shift of the signal observed at $1149 \mathrm{~cm}^{-1}$ to lower frequencies at $1126 \mathrm{~cm}^{-1}$ and the merger of the two signals noted at 1057 and $1028 \mathrm{~cm}^{-1}$ to form one broad signal with a peak at $1036 \mathrm{~cm}^{-1}$. Similarly, with regard to the complex with zinc(II), the structural arrangement of Na-Cyanex 272-cobalt(II) complex does not depend on the ligand:metal molar ratio.

\section{Conclusions}

Converting Cyanex 272 into its sodium salt significantly improves the efficiency of extraction in comparison to that performed with the acidic form of the extractant, regardless of the type of metal ion considered, $\mathrm{Zn}$ (II) or $\mathrm{Co}$ (II). Stripping of metal ions from Na-Cyanex 272 causes transformation of the salt into the acidic form of the extractant. The phenomena occurring in the extraction system are confirmed by the obtained FT-IR spectra of the organic phases after extraction and stripping. A comparison of FT-IR spectra shows the contribution of BHT and decan-1-ol to the coordination of metal ions extracted.

This novel approach to extraction of metal ions from CNS with sodium salt of Cyanex 272 proved that the change in initial $\mathrm{pH}$ of feeds does not have a negative effect on the extraction efficiency, which is a great advantage of the basic form of the extractant over its acidic form. Regarding the presence of other metal ions in real CNS, negative effect of high content of $\mathrm{Ni}(\mathrm{II})$ on the efficiency and selectivity of other metal ion extraction from the solution is indicated. Although Co(II) separation from 
$\mathrm{Zn}$ (II) is possible from model solution, the selectivity of their separation from real CNS solution is not efficient. Results of the selectivity of extraction with Na-Cyanex 272 for an industrial solution indicate that $\mathrm{Ni}$ (II) should be removed from the aqueous mixture prior to extraction with Na-Cyanex 272. Further, the mixture of $\mathrm{Zn}(\mathrm{II}), \mathrm{Co}(\mathrm{II})$, and $\mathrm{Cu}(\mathrm{II})$ can be processed.

Acknowledgments This work was supported by the 03/32/DS-PB/ 0601 and 03/32/DS-PB/0600 grants.

Open Access This article is distributed under the terms of the Creative Commons Attribution 4.0 International License (http://crea tivecommons.org/licenses/by/4.0/), which permits unrestricted use, distribution, and reproduction in any medium, provided you give appropriate credit to the original author(s) and the source, provide a link to the Creative Commons license, and indicate if changes were made.

\section{References}

Al-Gheethi AAS, Lalung J, Noman EA, Bala JD, Norli I (2015) Removal of heavy metals and antibiotics from treated sewage effluent by bacteria. Clean Technol Environ Policy 17:2101-2123. doi:10.1007/s10098-015-0968-Z

Cole PM, Sole KC (2003) Zinc solvent extraction in the process industries. Mineral Proc Extr Metall Rev 24:91-137

Cytec Industries Inc. (2008) CYANEX ${ }^{\circledR} 272$ extractant folder. www. cytec.com. Accessed 3 Jan 2015

Devi NB, Nathsarma KC, Chakravortty V (1994) Sodium salts of D2EHPA, PC-88A and Cyanex-272 and their mixtures as extractants for cobalt(II). Hydrometallurgy 34:331-342

Devi NB, Nathsarma KC, Chakravortty V (1997) Extraction and separation of $\mathrm{Mn}$ (II) and $\mathrm{Zn}$ (II) from sulphate solutions by sodium salt of Cyanex 272. Hydrometallurgy 45:169-179

Devi NB, Nathsarma KC, Chakravortty V (1998) Separation and recovery of cobalt(II) and nickel(II) from sulphate solutions using sodium salts of D2EHPA, PC 88A and Cyanex 272. Hydrometallurgy 49:47-61

Drąg P, Pawłowski J, Jusiak S, Kuśpit K, Chwalik H, Żuchowski Z, Pisarczyk G, Batorski H (1989) Polish Patent. No. 147371

Gotfryd L (2006) Solvent extraction of cobalt(II) from indigenous byproducts. Przem Chem 8-9:810-813

Kang J, Senanayake G, Sohn J, Shin SM (2010) Recovery of cobalt sulfate from spent lithium ion batteries by reductive leaching and solvent extraction with Cyanex 272. Hydrometallurgy 100:168-171. doi:10.1016/j.hydromet.2009.10.010

Kerfoot DGE, Krause E, Love BJ, Singhal A (2002) Hydrometallurgical process for the recovery of nickel and cobalt values from a sulfidic flotation concentrate, US Patent. US 6,428,604 B1

KGHM, www.kghm.pl, Accessed Jan 2015

Kongolo K, Mwema MD, Banza AN, Gock E (2003) Cobalt and zinc recovery from copper sulphate solution by solvent extraction. Min Eng 16:1371-1374. doi:10.1016/j.mineng.2003.09.001

Kumar N, Bauddh K, Kumar S, Dwivedi N, Singh DP, Barman SC (2013) Extractability and phytotoxicity of heavy metals present in petrochemical industry sludge. Clean Technol Environ Policy 15:1033-1039. doi:10.1007/s10098-012-0559-1

Li L, Qu W, Zhang X, Lu J, Chen R, Wu F, Amine K (2015) Succinic acid-based leaching system: a sustainable process for recovery of valuable metals from spent Li-ion batteries. J Power Sources 282:544-551. doi:10.1016/j.jpowsour.2015.02.073

Markusson N (2011) Unpacking the black box of cleaner technology. J Cleaner Prod 19:294-302. doi:10.1016/j.jclepro.2010.10.007

Metrohm (2015a) Nickel and cobalt in drinking water. VA Application Note No. V-87. http://products.metrohm.com/getAttach ment.axd?attaName=84373052-d4e1-482f-8d0e-e1a9135aab81. Accessed 3 Jan 2015

Metrohm (2015b) Voltammetric determination of zinc, cadmium, lead, copper, thallium, nickel, and cobalt in water samples according to DIN 38406 Part 16. VA Application Note No. 231/2 e. Accessed 3 Jan 2015

Mishra V, Balomajumder C, Agarwal VK (2014) Biological removal of heavy metal zinc from industrial effluent by Zinc sequestering bacterium VMSDCM. Clean Technol Environ Policy 16:555-568. doi:10.1007/s10098-013-0655-x

Moritomo H, Makoto N, Takeshi H, Koji N (2014) Method for recovering nickel from copper electrolyte, Japanese Patent. JP2014159633

Olejnik A, Gotfryd L, Kwarciński M (2008) Cleaning technologies of crude nickel sulphate—pilot scale studies. Ekopartner 9:41 (in Polish)

Parhi PK, Sarangi K (2008) Separation of copper, zinc, cobalt and nickel ions by supported liquid membrane technique using LIX 84I, TOPS-99 and Cyanex272. Sep Purif Technol 59:169-174. doi:10.1016/j.seppur.2007.06.008

Reddy BR, Park KH (2007) Process for the recovery of cobalt and nickel from sulphate leach liquors with saponified Cyanex 272 and D2EHPA. Sep Sci Technol 42(9):2067-2080. doi:10.1080/ 01496390701310496

Ritcey GM (2006) Solvent Extraction in Hydrometallurgy: present and Future. Tsinghua Sci Technol 11(2):137-152

Rydberg J, Cox M, Musicas C, Choppin GR (2004) Principles and practices of solvent extraction. Marcel Dekker, New York

Sarangi K, Reddy BR, Das RP (1999) Extraction studies of cobalt(II) and nickel(II) from chloride solutions using Na-Cyanex 272. Separation of $\mathrm{Co}(\mathrm{II}) / \mathrm{Ni}(\mathrm{II})$ by the sodium salts of D2EHPA, PC88A and Cyanex 272 and their mixtures. Hydrometallurgy 52:253-265

Sethu VS, Aziz AR, Aroua MK (2008) Recovery and reutilisation of copper from metal hydroxide sludges. Clean Technol Environ Policy 10:131-136. doi:10.1007/s10098-007-0133-4

Sole KC, Hiskey JB (1995) Solvent extraction of copper by Cyanex 272, Cyanex302 and Cyanex 301. Hydrometallurgy 37:129-147

Sole KC, Feather AM, Cole PM (2005) Solvent extraction in southern Africa: an update of some recent hydrometallurgical developments. Hydrometallurgy 78:52-78. doi:10.1016/j.hydromet. 2004.11.012

Staszak K, Regel-Rosocka M, Wieszczycka K, Burmistrzak P (2012) Copper(II) sulphate solutions treatment by solvent extraction with Na-Cyanex 272. Sep Purif Technol 85:183-192. doi:10. 1016/j.seppur.2011.10.010

Van de Voorde I, Pinoy L, Courtijn E, Verpoort F (2006) Equilibrium studies of nickel(II), copper(II), and cobalt(II) extraction with Aloxime 800, D2EHPA, and Cyanex reagents. Solvent Extr Ion Exch 24:893-914. doi:10.1080/07366290600952717

Zhu Z, Pranolo Y, Zhang W, Cheng CY (2011) Separation of cobalt and zinc from concentrated nickel sulfate solutions with Cyanex 272. J Chem Technol Biotechnol 86:75-81. doi:10.1002/jctb. 2501

Zinicovscaia I, Duca G, Cepoi L, Chiriac T, Rudi L, Mitina T, Frontasyeva MV, Pavlov S, Gundorina SF (2015) Biotechnology of metal removal from industrial wastewater: zinc case study. Clean Soil Air Water 43:112-117. doi:10.1002/clen.201200570 